Article

\title{
Structure and Thermal Properties of 2,2'-Azobis(1H-Imidazole-4,5-Dicarbonitrile)-A Promising Starting Material for a Novel Group of Energetic Compounds
}

\author{
Rafał Lewczuk $^{1, *(\mathbb{D}, \text { Maria Książek }}{ }^{2}$, Katarzyna Gańczyk-Specjalska ${ }^{1}$ and Katarzyna Cieślak ${ }^{3}$ (I) \\ 1 Department of High-Energetic Materials, Łukasiewicz Research Network-Institute of Industrial Organic \\ Chemistry, Annopol 6, 03-236 Warsaw, Poland; specjalska@ipo.waw.pl \\ 2 Institute of Physics, University of Silesia, 75 Pułku Piechoty 1, 41-500 Chorzów, Poland; \\ maria.ksiazek@us.edu.pl \\ 3 Division of High Energetic Materials, Warsaw University of Technology, Noakowskiego 3, 00-664 Warsaw, \\ Poland; kcieslak@ch.pw.edu.pl \\ * Correspondence: lewczuk@ipo.waw.pl
}

Received: 12 December 2019; Accepted: 9 January 2020; Published: 13 January 2020

check for updates

\begin{abstract}
A high-nitrogen compound, 2,2'-azobis( $1 H$-imidazole-4,5-dicarbonitrile) (TCAD), was synthesized from commercially available 2-amino- $1 H$-imidazole-4,5-dicarbonitrile. It was characterized with infrared and nuclear magnetic resonance spectroscopy. Its structure was determined by single crystal X-ray diffraction. The crystal of TCAD tetrahydrate is monoclinic, with space group P2 1 /c with crystal parameters of $\mathrm{a}=10.2935(2) \AA, \mathrm{b}=7.36760(10) \AA, \mathrm{c}=20.1447(4) \AA$, $\mathrm{V}=1500.27(5) \AA^{3}, \mathrm{Z}=4$, and $\mathrm{F}(000)=688$. Computational methods were used in order to fully optimize the molecular structure, calculate the electrostatic potential of an isolated molecule, and to compute thermodynamic parameters. TCAD has very high thermal stability with temperature of decomposition at $369^{\circ} \mathrm{C}$. Kinetics of thermal decomposition of this compound were studied and apparent energy of activation as well as the maximum safe temperature of technological process were determined.
\end{abstract}

Keywords: synthesis; high-nitrogen materials; thermal analysis; azo compounds

\section{Introduction}

Energetic materials are chemical entities with energy stored in their molecules. They belong to the various classes of organic and inorganic compounds. To name some of them, there are aliphatic and aromatic nitro compounds (nitromethane, 2,4,6-trinitrotoluene), nitroamines (ethylenedinitramine), esters (glyceryl trinitrate), and inorganic salts (lead azide, ammonium nitrate). In the last decades, we can observe an intense development of another class-aromatic heterocyclic energetics, which exhibit interesting properties suitable for many applications (e.g.: gas generants, environmentally friendly pyrotechnics) [1-6]. A distinctive group is formed by azo-bridged azoles and azines [7]. These compounds have large positive heats of formation and often show remarkable insensitivity toward electrostatic discharge, friction, and impact. Moreover, these molecules usually have better performance than parent non-linked heterocycles since they contain the azo explosophore moiety [7]. Amongst the most important energetic azo compounds, there are derivatives of 1,2,3,4-tetrazine (Figure 1, 1a), tetrazole (1b), 1,2,4-triazole (1c), and pyrazole (1d) [8-11]. Nitrated imidazoles are of great interest due to their low sensitivity towards various stimuli and high detonation parameters, but 
no compounds with 2,2'-azobis( $1 H$-imidazole) as a core have been synthesized with their possible explosive properties in mind [12-15].<smiles>Nc1nnc(N=Nc2nnc(N)nn2)nn1</smiles><smiles></smiles><smiles>O=[N+]([O-])c1nnc(N=Nc2nnc([N+](=O)[O-])[nH]2)[nH]1</smiles><smiles>O=[N+]([O-])c1cc([N+](=O)[O-])n(/N=N/n2nc([N+](=O)[O-])cc2[N+](=O)[O-])n1</smiles>

Figure 1. Some of the energetic azo compounds: 3,3'-azobis(6-amino-1,2,4,5-tetrazine) (1a), diammonium 5,5'-azobis(tetrazolate) (1b), 5,5'-dinitro-3,3'-azobis $(1 H-1,2,4$-triazole) (1c), and 1,1'-azobis(3,5-dinitropyrazole) (1d).

Nevertheless, several derivatives with aliphatic or aromatic substituents have been reported and they may serve as photoswitches and dyes [16-21]. 2,2'-Azobis(1H-imidazole-4,5-dicarbonitrile) (TCAD), its alkyl derivatives, salts, metal complexes, hydrolysis products, hydrazine, and hydroxylamine adducts were recognized as dyes as well [22]. Taking into consideration that some of the polynitriles, such as $N, N^{\prime}, N^{\prime \prime}-(1,3,5$-triazine-2,4,6-triyl)tris( $N$-cyanocyanamide) (Figure 2, 2a), 1,2,5-oxadiazole-3,4-dicarbonitrile (2b), and pyrazine-2,3,5,6-tetracarbonitrile (2c), were recognized to be energetics and substrates for high-nitrogen compounds, TCAD with its azo bridge is likely to be even more energetic [23-25].

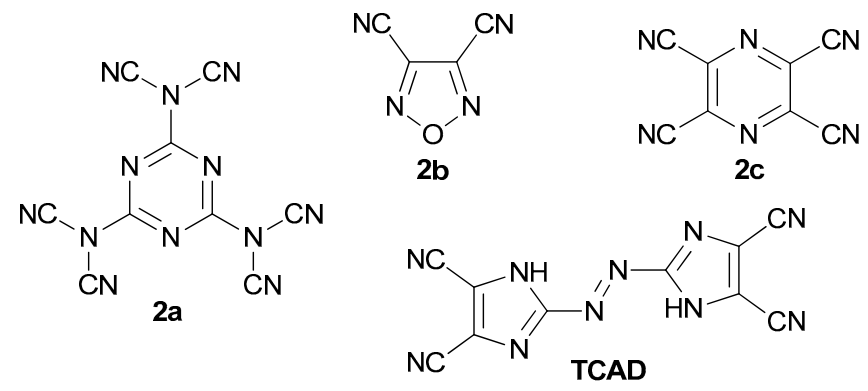

Figure 2. Structures of known energetic polynitriles.

Therefore, for the first time, we present the molecular structure of TCAD in the crystalline state, determined using low-temperature single crystal X-ray diffraction. TCAD crystallizes from water with four water molecules per TCAD molecule in the monoclinic space group $P 2_{1} / c$, with a density of $1.480 \mathrm{~g} \mathrm{~cm}^{-3}$ at $100 \mathrm{~K}$ and four molecules in the unit cell. The geometry of the molecule was optimized using the B3LYP/cc-pVDZ level of theory. Afterwards, the enthalpy of formation of TCAD was calculated using CBS-4M with the Gaussian 09 (Revision E.01) software [26]. The prepared compound was characterized by elemental analysis, nuclear magnetic resonance, and infrared spectroscopy. It has exceptionally high decomposition temperature so herein the results of the studies of the kinetics of thermal decomposition are reported.

\section{Results and Discussion}

\subsection{Crystal Structure}

The title compound crystallizes in the monoclinic $P 2_{1} / c$ space group with one molecule of TCAD and four water molecules. Imidazole rings lie in a plane which suggests that bonds are strongly coupled. The 
C8-N7 bond length is $1.402 \AA$ and the length of the $\mathrm{N}=\mathrm{N}$ bond of the azo bridge is $1.266 \AA$. Similar angles and distances can be found in other azo derivatives of azoles: 4,4'-azobis(3,5-diazido-1,24-triazole) (1.38 $\AA$, $1.25 \AA$, resp.) [27], 3,3'-azobis(5-(trinitromethyl)-1,2,4-triazole) (1.39 $\AA, 1.24 \AA$, resp.) [28], and in diammonium $5,5^{\prime}$-azobis(tetrazolate) $(1.40 \AA, 1.26 \AA$, resp.) [29]. All mentioned azo-bridged molecules are planar. The molecular structure of TCAD tetrahydrate and atomic numbering were shown in Figure 3. In Table 1, the crystal parameters, experimental, and refinement details are collected.

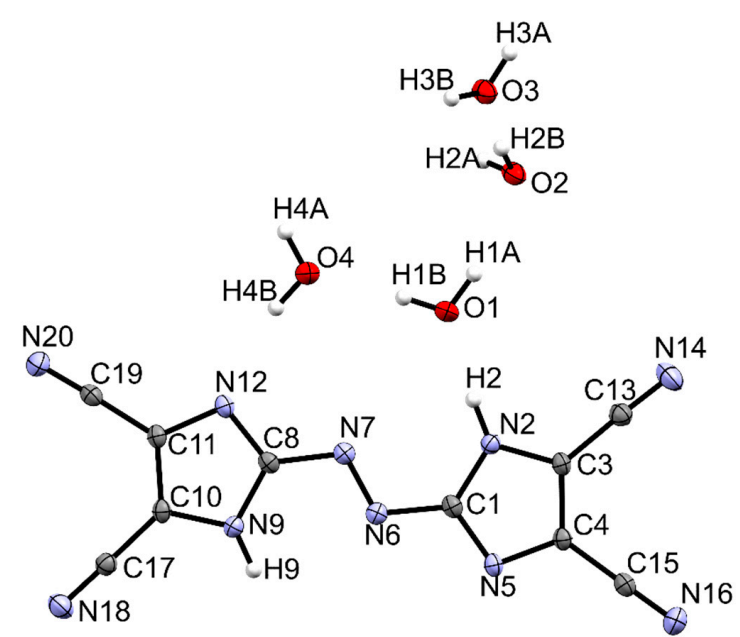

Figure 3. Crystal structure of TCAD $4 \mathrm{H}_{2} \mathrm{O}$. Ellipsoids are scaled at $50 \%$ probability.

Table 1. Crystal data and structure refinement for TCAD $4 \mathrm{H}_{2} \mathrm{O}$.

\begin{tabular}{|c|c|}
\hline Parameter & Value \\
\hline Empirical formula & $\mathrm{C}_{10} \mathrm{H}_{10} \mathrm{~N}_{10} \mathrm{O}_{4}$ \\
\hline Formula weight $[\mathrm{g} / \mathrm{mol}]$ & 334.28 \\
\hline Temperature $[\mathrm{K}]$ & $100(1)$ \\
\hline Wavelength $[\AA]$ & 0.71073 \\
\hline Crystal system & monoclinic \\
\hline Space group & $\mathrm{P} 2_{1} / \mathrm{c}$ \\
\hline \multicolumn{2}{|l|}{ Unit cell dimensions: } \\
\hline $\mathrm{a}[\AA]$ & $10.2935(2)$ \\
\hline $\mathrm{b}[\AA]$ & $7.36760(10)$ \\
\hline$c[\AA]$ & $20.1447(4)$ \\
\hline$\beta\left[^{\circ}\right]$ & $100.882(2)$ \\
\hline Volume $\left[\AA^{3}\right]$ & $1500.27(5)$ \\
\hline $\mathrm{Z}$ & 4 \\
\hline Density $\left[\mathrm{g} / \mathrm{cm}^{3}\right]$ & 1.480 \\
\hline Absorption coefficient $\left[\mathrm{mm}^{-1}\right]$ & 0.119 \\
\hline $\mathrm{F}(000)$ & 688 \\
\hline Crystal size [mm] & $0.07 \times 0.13 \times 0.27$ \\
\hline Theta range for data collection $\left[{ }^{\circ}\right]$ & 2.950 to 26.370 \\
\hline Index ranges & $-12 \leq h \leq 12,-9 \leq k \leq 7,-25 \leq l \leq 25$ \\
\hline Reflections collected & 12183 \\
\hline Independent reflections & $3067\left[\mathrm{R}_{(\mathrm{int})}=0.0159\right]$ \\
\hline Completeness to theta $=25.242^{\circ}[\%]$ & 99.9 \\
\hline Refinement method & Full-matr-ix least-squares on $\mathrm{F}^{2}$ \\
\hline Data/restraints/parameters & $3067 / 0 / 229$ \\
\hline Goodness-of-fit on $\mathrm{F}^{2}$ & 1.035 \\
\hline Final $\mathrm{R}$ indices $[\mathrm{I}>2$ sigma(I)] & $\mathrm{R} 1=0.0341, \mathrm{wR} 2=0.0921$ \\
\hline $\mathrm{R}$ indices (all data) & $\mathrm{R} 1=0.0364, \mathrm{wR} 2=0.0947$ \\
\hline Largest diff. peak and hole & 0.396 and -0.224 \\
\hline
\end{tabular}

Crystal structure exhibits strong hydrogen bonding. Hydrogen bonds are formed between the $\mathrm{N}-\mathrm{H}$ as $\mathrm{H}$-bond donors (D) and $\mathrm{N}$ or $\mathrm{O}$ atoms as $\mathrm{H}$-bond acceptors (A). The presence of water molecules in the crystal structure also promotes the formation of hydrogen bonds. There can be distinguished two types of such bonds- between water molecules and the molecule of TCAD $(\mathrm{O}-\mathrm{H} \cdots \mathrm{N})$ and only 
between water molecules $(\mathrm{O}-\mathrm{H} \cdots \mathrm{O})$. According to the classification proposed by Desiraju and Steiner, the $\mathrm{O}-\mathrm{H} \cdots \mathrm{O}$ and $\mathrm{N}-\mathrm{H} \cdots \mathrm{O}$ interactions are strong, while the $\mathrm{N}-\mathrm{H} \cdots \mathrm{N}$ and $\mathrm{O}-\mathrm{H} \cdots \mathrm{N}$ hydrogen bonds are weak [30]. H-bond parameters for the studied compound and the results of the Hirshfeld surfaces analysis were collected in the Supporting Information.

\subsection{Physiochemical Properties}

The standard molar enthalpy of formation and standard molar enthalpy of combustion of TCAD

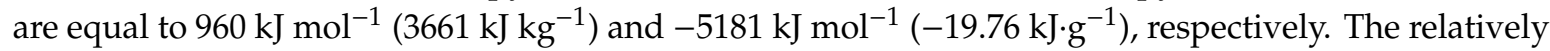

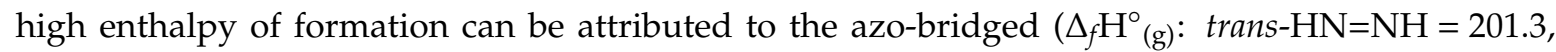
trans $-\mathrm{H}_{3} \mathrm{C}-\mathrm{N}=\mathrm{N}-\mathrm{CH}_{3}=147.7$ versus $\left.\mathrm{H}_{3} \mathrm{CCH}_{3}=-83.8\left[\mathrm{~kJ} \mathrm{~mol}{ }^{-1}\right]\right)$ imidazoles skeleton $\left(\Delta_{f} \mathrm{H}^{\circ}(\mathrm{s})\right.$ : $1 H$-imidazole $=49.8,1 H$-pyrazole $=105.4\left[\mathrm{~kJ} \mathrm{~mol}^{-1}\right]$ ) [31-33]. Further functionalization of the imidazoles rings in 4, 5 positions via [ $2+3$ ] dipolar azide-nitrile cycloaddition reaction could yield in a highly promising energetic material, namely the tetratetrazolo-congener $(\mathrm{N}=70.95 \%)$.

The sensitivity to impact of a compound can be connected to the electrostatic potential (ESP) of an isolated molecule [34-37]. The ESP of TCAD on the 0.001 electron bohr ${ }^{-3}$ hypersurface, with the color coding ranged from red $(V(r) \leq-0.075$ hartree) for electron-rich regions to blue $(V(r) \geq+0.075$ hartree) for electron-deficient regions, is shown in Figure 4 [38].

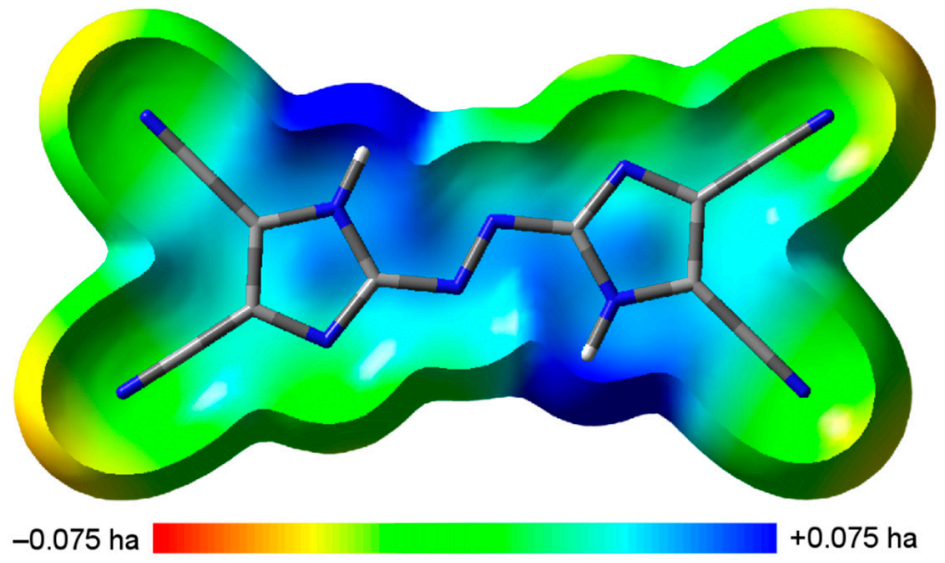

Figure 4. Calculated electrostatic potential of TCAD (view perpendicular to the plane).

TCAD can be characterized by stronger and much smaller negative electrostatic potential regions than positive ones, which can be attributed to low-impact-sensitive covalent species (details are given in the Supporting Information) [34-37]. Sensitivity to mechanical stimuli of anhydrous TCAD was also determined experimentally. There was no positive response for the impact energy $30 \mathrm{~J}$ and for the friction force $360 \mathrm{~N}$. It indicates insensitivity of the tested compound. Experimental results are in accordance with computations.

During differential thermal analysis (DTA) coupled with thermogravimetry (TG) measurement with a heating rate $\beta=5{ }^{\circ} \mathrm{C} \mathrm{min}^{-1}$, mass loss of TCAD proceeded in two steps. The first one began at $118^{\circ} \mathrm{C}(-1.7 \%)$, the second one at $340{ }^{\circ} \mathrm{C}(-23.4 \%)$. First, the endothermic signal was observed on a DTA curve at $147.1^{\circ} \mathrm{C}$ (maximum peak temperature) and it can be assigned to the loss of water which was not removed during the drying process. Second, the signal at $370.2^{\circ} \mathrm{C}$ was exothermic and it was connected to thermal decomposition. The temperature of decomposition, the onset point of the peak, was $368.7^{\circ} \mathrm{C}$.

As expected, the decomposition process had occurred at a higher temperature, as the heating rate was increased. The maximum peak temperatures were observed in a range from $354{ }^{\circ} \mathrm{C}$ to $374{ }^{\circ} \mathrm{C}$. Another exothermic process was observed on the right sides of peaks for some heating rates ( 5 and $\left.10{ }^{\circ} \mathrm{C} \mathrm{min}^{-1}\right)$. This means that decomposition of TCAD is a complex process-multiple reactions may take place simultaneously and/or sequentially during transition. Because of this reason, the calculated 
activation energy in the next part of this manuscript was called apparent activation energy. The kinetic analysis of the decomposition process was determined using DTA and TG curves. The dependences of apparent activation energy $(E)$ and the natural logarithm of the pre-exponential factor $(\ln A)$ on the conversion degree for TCAD achieved in DTA and TG measurements are shown in Figure 5.

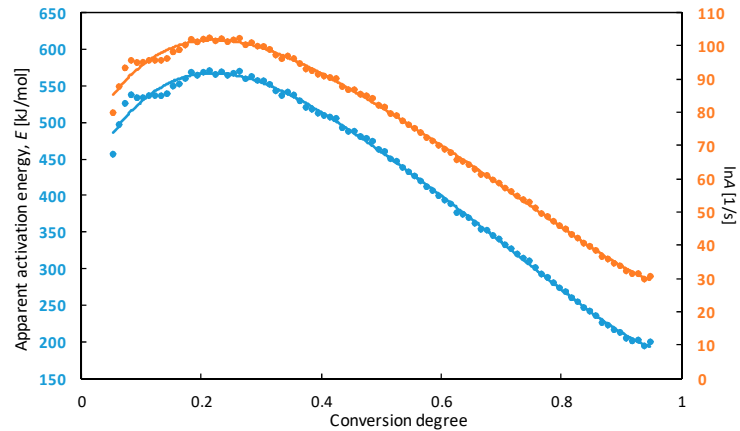

(a)

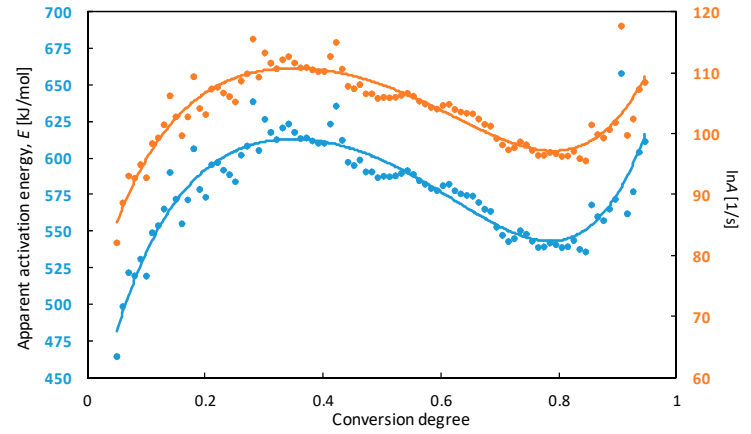

(b)

Figure 5. The dependence of apparent activation energy $(E)$ and the natural logarithm of the pre-exponential factor $(\ln A)$ on the conversion degree for TCAD achieved in DTA (a) and TG (b) measurements.

The characteristics of $\ln A$ and $E$ change with a similar pattern. The apparent activation energy calculated from results of DTA experiments increased from approx. 480 to $570 \mathrm{~kJ} \mathrm{~mol}^{-1}$ and $\ln A$ increased from approx. 85 to 103 in a range of conversion degree $\alpha=0.05-0.20$. Then, $E$ decreased to $200 \mathrm{~kJ} \mathrm{~mol}^{-1}$ and $\ln A$ to 30 .

The dependences calculated from TG measurements correspond to three-stage processes. In the range of conversion degree $\alpha=0.05-0.35$, apparent activation energy increased from approx. 480 to $610 \mathrm{~kJ} \mathrm{~mol}^{-1}$ then decreased to $540 \mathrm{~kJ} \mathrm{~mol}^{-1}(\alpha=0.80)$ and increased again to $615 \mathrm{~kJ} \mathrm{~mol}^{-1}(\alpha=0.95)$. In the first stage, $\ln A$ increased from 85 to 110 . Next, it decreased to $97(\alpha=0.80)$ and increased to 110 $(\alpha=0.95)$.

Major changes of the apparent activation energy with the conversion degree are connected with many thermally initiated process (e.g. reactions, physical transitions) taking place during TCAD decomposition. The apparent activation energy for low conversion degree $(\alpha=0.05)$ equals to approx. $480 \mathrm{~kJ} \mathrm{~mol}^{-1}$ for both DTA and TG measurements. Since the runaway decomposition of high-energetic materials can occur for low conversion degree and it can lead to thermal explosion, that value could be used for determination of thermal stability of the compound $[39,40]$. The parameters which allows to analyze the thermal explosion hazard are e.g., maximum safe operating temperature of technological processes and self-accelerating decomposition temperature [41]. The $100{ }^{\circ} \mathrm{C}$ rule is the simplest method for determination of maximum safe temperature of technological process based on DTA measurements [42]. The maximum safe temperature is $100^{\circ} \mathrm{C}$, lower than the maximum temperature of the decomposition peak on the DTA curve (measurements for $10^{\circ} \mathrm{C} \mathrm{min}^{-1}$ ). The maximum temperature of TCAD decomposition is $373.5 \pm 0.7^{\circ} \mathrm{C}$ and the maximum safe temperature of technological process for this compound equals to $274{ }^{\circ} \mathrm{C}$, according to the $100{ }^{\circ} \mathrm{C}$ rule.

\section{Materials and Methods}

\subsection{General Information}

High-purity sodium nitrate(III), sodium sulphate(IV), and hydrochloric acid were purchased from Sigma-Aldrich (Steinheim, Germany). 2-Amino-4,5-dicyano-1H-imidazole (ABCR, product no. AB136180) was used as supplied. Melting point of the product was determined with an Electrothermal 9200 melting point apparatus. Elemental analysis of TCAD was performed with a Vario El Cube CHNS-O-Cl analyzer in the CHN mode. The Fourier transform infrared spectroscopy (FTIR) analysis 
was performed using Thermo Scientific NICOLET 6700 spectrometer (Waltham, MA, USA) with ATR (Attenuated Total Reflectance) unit. The FTIR spectra was recorded in the wave number range: $400-4000 \mathrm{~cm}^{-1}$ with a resolution of $2 \mathrm{~cm}^{-1}$. ${ }^{1} \mathrm{H}$ and ${ }^{13} \mathrm{C}-\mathrm{NMR}$ spectra were recorded on a Bruker Avance III spectrometer (Bruker, Coventry, UK) (500 and $125 \mathrm{MHz}$, respectively). The chemical shifts in ${ }^{1} \mathrm{H}$ and ${ }^{13} \mathrm{C}-\mathrm{NMR}$ spectra were given with respect to TMS as the external standard. The mechanical sensitivity was determined by using standard BAM fall hammer for the impact sensitivity (IS) and BAM friction tester for friction sensitivity (FS). Tests were conducted according to United Nations recommendations [43].

\subsection{Synthesis}

TCAD was obtained according to Carlson's method [22].

2-Amino-1H-imidazole-4,5-dicarbonitrile (75 mmol, $9.98 \mathrm{~g}$ ) was dissolved in water ( $300 \mathrm{~mL})$, mixed with $38 \%$ water solution of hydrochloric acid $(66 \mathrm{~mL})$ at $0{ }^{\circ} \mathrm{C}$. Afterwards, a solution of sodium nitrite $(130 \mathrm{mmol}, 8.97 \mathrm{~g})$ in water $(25 \mathrm{~mL})$ was added dropwise over 10 minutes. The mixture was stirred for $1 \mathrm{~h}$ at $0{ }^{\circ} \mathrm{C}$. Subsequently, a solution of anhydrous sodium sulfite $(90 \mathrm{mmol}, 11.34 \mathrm{~g})$ in water $(60 \mathrm{~mL})$ was added at once to the vigorously stirred suspension of, generated in situ from obtained 4, 5-dicyanoimidazole-2-diazonium chloride, 2-diazo-4,5-dicyanoimidazole [44]. The bright yellow mixture was stirred for $30 \mathrm{~min}$ at $0{ }^{\circ} \mathrm{C}$ and filtered. The yellow precipitate was washed with acidified cold water and dried at $60^{\circ} \mathrm{C}$. The crude product was recrystallized from boiling water and dried at $60{ }^{\circ} \mathrm{C}$ to remove water molecules. Total yield: $2.46 \mathrm{~g}(25 \%)$. M.p. $=369-371{ }^{\circ} \mathrm{C}$ (decomp.). FTIR $\left(\mathrm{cm}^{-1}\right)$ v: $3162(\mathrm{~s}), 3070(\mathrm{w}), 2945(\mathrm{w}), 2247(\mathrm{vs}), 1540(\mathrm{w}), 1490(\mathrm{w}), 1421(\mathrm{~m}), 1209(\mathrm{~s}), 1033(\mathrm{~s}), 729(\mathrm{vs})$; ${ }^{1} \mathrm{H}-\mathrm{NMR}$ (DMSO- $\left.d_{6}, 500 \mathrm{MHz}\right): \delta 8.56(\mathrm{~s}, 2 \mathrm{H}) ;{ }^{13} \mathrm{C}-\mathrm{NMR}$ (DMSO- $\left.d_{6}, 125 \mathrm{MHz}\right): \delta 112.9(\mathrm{~s}), 119.2(\mathrm{~s})$, 159.7 (d); anal. calcd for $\mathrm{C}_{10} \mathrm{H}_{2} \mathrm{~N}_{10}$ : $\mathrm{C}, 45.81 ; \mathrm{H}, 0.77 ; \mathrm{N}, 53.42$; found: $\mathrm{C}, 45.60 ; \mathrm{H}, 0.81 ; \mathrm{N}, 53.29 \%$.

\subsection{X-Ray Crystallography}

Suitable crystal for the measurement was obtained by slow evaporation of water solution of TCAD. Crystal data were collected using a SuperNova diffractometer (Agilent Technologies, Santa Clara, CA, USA) with Atlas detector using mirror monochromator $\left(\mathrm{MoK}_{\alpha}\right.$ radiation, $\lambda=0.71073 \AA$ ). Accurate cell parameters were determined and refined using the CrysAlis ${ }^{\text {Pro }}$ program (ver. 1.171.38.41q, Rigaku Oxford Diffraction, 2015, Wrocław Poland). For the integration of the collected data, the same program was used. The structures were solved using the direct method with SHELXS-2013 software (Universität Göttingen, Lower Saxony, Germany) and the solution was refined with SHELXL-2018/3 [45]. All non-hydrogen atoms were refined with anisotropic displacement parameters. Hydrogen atoms were treated as "riding" on their parent carbon atoms with $d(\mathrm{C}-\mathrm{H})=0.88 \AA$ and $U_{\mathrm{iso}}(\mathrm{H})=1.2 U_{\mathrm{eq}}(\mathrm{C})$ for aromatic $\mathrm{H}$ and $\mathrm{N}-\mathrm{H}$ atoms. Water molecules were refined as a rigid group with $d(\mathrm{O}-\mathrm{H})=0.87 \AA$ and $U_{\text {iso }}(\mathrm{H})=1.5 U_{\text {eq }}(\mathrm{O})$. The details relating to the atomic coordinates, complete geometry of molecules, and all crystallographic data are deposited at the Cambridge Crystallographic Data Center (CCDC). CCDC-1862760 contains the supplementary crystallographic data for this paper. These data can be obtained free of charge via http://www.ccdc.cam.ac.uk/conts/retrieving.html.

\subsection{Computations}

The structure of TCAD was fully optimized without any symmetry constraints and was found to represent true minima $\left(C_{2 h}\right.$ symmetry; number of imaginary frequencies, NIMAG $\left.=0\right)$. The gas phase absolute molar enthalpy of TCAD at the standard conditions ( $298 \mathrm{~K}$ and $1 \mathrm{~atm}$ ) was computed theoretically, applying the modified complete basis set method (CBS-4M) with the Gaussian 09 (Revision E.01) software [26]. The gas phase molar enthalpy of formation at the standard conditions of TCAD was calculated using the atomization energy method [46-48]. The standard molar enthalpy of formation $\left(\Delta_{f} \mathrm{H}^{\circ}(\mathrm{s})\right)$ was calculated using the gas phase standard molar enthalpy and the standard molar enthalpy of sublimation (applying Trouton's rule) [49]. Additionally, standard molar enthalpy of combustion 
$\left(\Delta_{c} \mathrm{H}^{\circ}(\mathrm{s})\right.$ was calculated assuming the reaction shown in Scheme 1 (details are given in the Supporting Information).

$$
\mathrm{C}_{10} \mathrm{H}_{2} \mathrm{~N}_{10}+10.5 \mathrm{O}_{2} \longrightarrow 10 \mathrm{CO}_{2}+\mathrm{H}_{2} \mathrm{O}+5 \mathrm{~N}_{2}
$$

Scheme 1. The chemical equation for stoichiometric combustion of TCAD in oxygen.

\subsection{Thermal Analysis}

DTA/TG analyses were performed using Setaram Labsys ${ }^{\mathrm{TM}}$ Evo calorimeter (Caluire, France). All measurements were done in open aluminum crucibles in argon atmosphere. Mass of each sample was $7.5 \pm 0.2 \mathrm{mg}$. DTA/TG analyses were carried out using five different heating rates from 0.5 to $10^{\circ} \mathrm{C}-\mathrm{min}^{-1}$; the measurements for minimum and maximum heating rates were repeated three times in accordance with recommendations [50]. Kinetic parameters of the decomposition process were calculated using AKTS Thermokinetics Software. The activation energy and pre-exponential factor were calculated using the differential isoconversional method.

\section{Conclusions}

2,2'-Azobis( $1 H$-imidazole-4,5-dicarbonitrile) can be easily synthesized from commercially available substrates. It crystallizes from water as a tetrahydrate, of which the crystal structure was determined with single crystal X-ray crystallography. TCAD is planar and it is hydrogen-bonded with molecules of water. The calculated standard molar enthalpy of formation is very high $\left(960 \mathrm{~kJ} \mathrm{~mol}^{-1}\right)$ which is caused by significant contribution of the azo bridge. Strong negative electrostatic potential regions in the molecule indicate low sensitivity to impact. Large delocalization of electrons in the structure results in very good thermal stability. Temperature of decomposition is nearly $370{ }^{\circ} \mathrm{C}$. The apparent activation energy for the low conversion degree was calculated from DTA and TG results and it was very high $\left(480 \mathrm{~kJ} \mathrm{~mol}^{-1}\right)$. Finally, the maximum safe temperature of the technological process for TCAD was determined at $274{ }^{\circ} \mathrm{C}$.

Taking into consideration foregoing results, it could be concluded that TCAD is an interesting energetic molecule with excellent thermal stability and low sensitivity. It is a promising starting material for high-nitrogen compounds such as 2,2' -azobis[4,5-di(1H-tetrazol-5-yl)-1H-imidazole] (TTAZI) and 2,2'-azobis(4,7-diamino- $1 H$-imidazo[4,5,d]pyridazine). Tetrazoles derived from $\mathbf{2 a}, \mathbf{2} \mathbf{b}$, and $\mathbf{2} \mathbf{c}$ have decomposition temperatures way above $200{ }^{\circ} \mathrm{C}$ and 4,5-di(1H-tetrazol-5-yl)-1H-imidazol-2-amine decomposes at $227^{\circ} \mathrm{C}$ [51], so TTAZI with its $\pi$-electron conjugations could also have very good thermal stability. TCAD itself, which is a high-nitrogen nitrile similar to dicyandiamide, has a potential to be used in pyrotechnic fire extinguishers as a coolant and reductant, which can produce large quantities of nitrogen when combusted. Furthermore, 2,2'-azobis $(1 H$-imidazole) has huge potential to be a core structure in a brand new family of explosives with nitro-, nitramino-, and amino-substituents. The fact that protons in TCAD are acidic can lead to a whole group of energetic salts and complex compounds. The possibilities mentioned above endorse to continue research on $2,2^{\prime}$-azobis $(1 H$-imidazole) derivatives.

Supplementary Materials: The following are available online, Figure S1: The fragment of the net of the interand intramolecular contacts in TCAD $4 \mathrm{H}_{2} \mathrm{O}$, Figure S2: Two-dimensional fingerprint plot for the compound TCAD $4 \mathrm{H}_{2} \mathrm{O}$, Figure S3: The 2D fingerprint plot resolved into $\mathrm{N} \cdots \mathrm{H}$ (left), $\mathrm{H} \cdots \mathrm{N}$ (center), and $\mathrm{N} \cdots \mathrm{N}$ (right) interactions for TCAD $4 \mathrm{H}_{2} \mathrm{O}$, Figure S4: Calculated electrostatic potential of TCAD (view perpendicular to the plane through the atoms), Figures S5-S7: NMR spectra of TCAD, Figure S8: FT-IR spectrum of TCAD, Figure S9: DTA/TG thermogram of TCAD (heating rate: $5{ }^{\circ} \mathrm{C} / \mathrm{min}$ ), Figure S10: DTA curves of TCAD for various heating rates, Figure S11: TG curves of TCAD for various heating rates, Table S1: Selected hydrogen bond parameters in TCAD $4 \mathrm{H}_{2} \mathrm{O}$, Table S2: Intermolecular contacts and their contributions to the Hirshfeld surface in TCAD $4 \mathrm{H}_{2} \mathrm{O}$, Table S3: Literature values for $\Delta_{f} H_{\left(g, A_{i}, 298 K\right)}^{\circ}$ and $H_{\left(g, A_{i}, 298 \mathrm{~K}\right)}^{\circ}$ obtained from theoretical calculations at the CBS-4M level of theory, Table S4: CBS-4M, gas-phase enthalpy, and standard molar enthalpy of formation for TCAD. 
Author Contributions: Conceptualization, supervision, synthesis, writing, R.L.; X-Ray crystallography, writing, M.K.; Thermal analysis, writing, K.G.-S.; Infrared spectroscopy, K.C. All authors have read and agreed to the published version of the manuscript.

Funding: This research was funded by Polish Ministry of Science and High Education, grant number 4180/E-142/S/2019.

Acknowledgments: Authors thank to Tomasz G. Witkowski for applying computational methods and to Eng. Mateusz Szala, Military University of Technology, Warsaw, Poland, for performing NMR analyses.

Conflicts of Interest: The authors declare no conflict of interest.

\section{References}

1. Gao, H.; Shreeve, J.N.M. Azole-based energetic salts. Chem. Rev. 2011, 111, 7377-7436. [CrossRef] [PubMed]

2. Pagoria, P.F.; Lee, G.S.; Mitchell, A.R.; Schmidt, R.D. A review of energetic materials synthesis. Thermochim. Acta 2002, 384, 187-204. [CrossRef]

3. Duan, B.; Liu, N.; Wang, B.; Lu, X.; Mo, H. Comparative theoretical studies on a series of nonvel energetic salts composed of 4,8-dihydrodifurazano[3,4-b,e]pyrazine-based anions and ammonium-based cations. Molecules 2019, 24, 3213. [CrossRef]

4. Zhang, P.; Kumar, D.; Zhang, L.; Shem-Tov, D.; Petrutik, N.; Chinnam, K.A.; Yao, C.; Pang, S.; Gozin, M. Energetic Butterfly: Heat-Resistant diaminodinitro trans-Bimane. Molecules 2019, 24, 4324. [CrossRef] [PubMed]

5. Wang, G.; Fu, Z.; Yin, H.; Chen, F.-X. Synthesis and properties [1,2,4]triazolo[4,3-b][1,2,4,5]tetrazine N-oxide explosives. Propellants Explos. Pyrotech. 2019, 44, 1010-1014. [CrossRef]

6. Wingard, L.A.; Sausa, R.C.; Guzmán, P.E.; Pesce-Rodriguez, R.; Sabatini, J.; Drake, G.W. Synthesis of bis-isoxazole-bis-ethylene dinitrate and bis-isoxazole-tetra-ethylene tetranitrate: Potential energetic plasticizers. Propellants Explos. Pyrotech. 2019, 44, 617-622. [CrossRef]

7. Qu, Y.; Babailov, S.P. Azo-linked high-nitrogen energetic materials. J. Mater. Chem. A 2018, 6, 1915-1940. [CrossRef]

8. Chavez, D.E.; Hiskey, M.A.; Gilardi, R.D. 3,3'-Azobis(6-amino-1,2,4,5-tetrazine): A novel high-nitrogen energetic material. Angew. Chem. Int. Ed. 2000, 39, 1791-1793. [CrossRef]

9. Hiskey, M.A.; Goldman, N.; Stine, J.R. High-nitrogen energetic materials derived from azotetrazolate. J. Energy Mater. 1998, 16, 119-127. [CrossRef]

10. Naud, D.L.; Hiskey, M.A.; Harry, H.H. Synthesis and explosive properties of 5,5'-dinitro-3,3'-azo-1H-1,2,4-triazole (DNAT). J. Energy Mater. 2003, 21, 57-62. [CrossRef]

11. Li, Y.-N.; Shu, Y.-J.; Wang, Y.-L.; Wang, B.-Z.; Zhang, S.-Y.; Bi, F.-Q. Synthesis, structure and energetic properties of a catenated $\mathrm{N}_{6}$, polynitro compound: 1,1'-azobis(3,5-dinitropyrazole). Cent. Eur. J. Energy Mater. 2017, 14, 321-335. [CrossRef]

12. Song, J.; Wang, K.; Liang, L.; Bian, C.; Zhou, Z. High-energy-density materials based on 1-nitramino-2,4-dinitroimidazole. RSC Adv. 2013, 3, 10859-10866. [CrossRef]

13. Yin, P.; He, C.; Shreeve, J.M. Fully C/N-polynitro-functionalized 2,2'-biimidazole derivatives as nitrogenand oxygen-rich energetic salts. Chem. Eur. J. 2016, 22, 2108-2113. [CrossRef] [PubMed]

14. Breiner, M.M.; Chavez, D.E.; Parrish, D.A. Nucleophilic reactions of the bis ammonium salt of 4,4', 5,5'-tetranitro-2,2'-biimidazole. Synlett 2013, 24, 519-521. [CrossRef]

15. Xu, Y.; Shen, C.; Lin, Q.; Wang, P.; Jiang, C.; Lu, M. 1-Nitro-2-trinitromethyl substituted imidazoles: A new family of high performance energetic materials. J. Mater. Chem. A 2016, 4, 17791-17800. [CrossRef]

16. Kreutzberger, A.; Schücker, R. Aliphatische Substitution in der Reihe der 2,2'-Azoimidazole. 10. Mitt. Kondensationen mit Hydrazin-N,N'-dicarbonsäure-diamidin. Arch. Pharm. 1972, 305, 935-940. [CrossRef]

17. Kreutzberger, A. Condensations with 1,2-hydrazinedicarboxamidine. II. 2,2'-Azoimidazoles. J. Org. Chem. 1962, 27, 886-891. [CrossRef]

18. Kreutzberger, A.; Schücker, R. 2,2'-Azoimidazolbildung durch cyclische Acyloine. 8. Mitt.: Kondensationen mit Hydrazin-N,N'-dicarbonsäure-diamidin. Arch. Pharm. 1972, 305, 400-405. [CrossRef]

19. Bull, J.N.; Scholz, M.S.; Coughlan, N.J.A.; Bieske, E.J. Isomerisation of an intramolecular hydrogen-bonded photoswitch: Protonated azobis(2-imidazole). Phys. Chem. Chem. Phys. 2017, 19, 12776-12783. [CrossRef] 
20. Weston, C.E.; Richardson, R.D.; Fuchter, M.J. Photoswitchable basicity through the use of azoheteroarenes. Chem. Commun. 2016, 52, 4521-4524. [CrossRef]

21. Rumyantsev, V.G.; Ivashchenko, A.V.; Muratov, V.M.; Lazareva, V.T.; Prudnikova, E.K.; Blinov, L.M. Dyes witth negative dichorism for liquid crystal displays based on the guest-host effect. Mol. Cryst. Liq. Cryst. 1983, 94, 205-212. [CrossRef]

22. Carlson, B.A. 2,2'-Azobis(4,5-imidazoledicarbonitrile) and derivatives. US4083843A, 11 April 1978.

23. Godovikova, T.I.; Vorontsova, S.K.; Konyushkin, L.D.; Firgang, S.I.; Rakitin, O.A. Synthesis of 5-(1,2,5-oxadiazol-3-yl)-1H-tetrazoles from 3-cyano-1,2,5-oxadiazoles. Russ. Chem. Bull. 2009, 58, 406-409. [CrossRef]

24. Rao, M.H.; Ghule, V.D.; Muralidharan, K. 2,4,6-Tris[bis(1H-tetrazol-5-yl)amino]-1,3,5-triazine as a nitrogen-rich material. J. Chem. Sci. 2017, 129, 657-661. [CrossRef]

25. Witkowski, T.G.; Sebastiao, E.; Gabidullin, B.; Hu, A.; Zhang, F.; Murugesu, M. 2,3,5,6-Tetra(1H-tetrazol-5-yl)pyrazine: A thermally stable nitrogen-rich energetic material. ACS Appl. Energy Mater. 2018, 1, 589-593. [CrossRef]

26. Frisch, M.J.; Trucks, G.W.; Schlegel, H.B.; Scuseria, G.E.; Robb, M.A.; Cheeseman, J.R.; Scalmani, G.; Barone, V.; Mennucci, B.; Petersson, G.A.; et al. Gaussian 09, Revision E.01; Gaussian, Inc.: Wallingford, CT, USA, 2009.

27. Qi, C.; Li, S.-H.; Li, Y.-C.; Wang, Y.; Zhao, X.-X.; Pang, S.-P. Synthesis and Promising Properties of a New Family of High-Nitrogen Compounds: Polyazido- and Polyamino-Substituted N,N'-Azo-1,2,4-triazoles. Chem. Eur. J. 2012, 18, 16562-16570. [CrossRef] [PubMed]

28. Thottempudi, V.; Shreeve, J.n.M. Synthesis and Promising Properties of a New Family of High-Density Energetic Salts of 5-Nitro-3-trinitromethyl-1H-1,2,4-triazole and 5,5'-Bis(trinitromethyl)-3,3'-azo- $1 \mathrm{H}$ 1,2,4-triazole. J. Am. Chem. Soc. 2011, 133, 19982-19992. [CrossRef] [PubMed]

29. Hammerl, A.; Holl, G.; Kaiser, M.; Klapötke Thomas, M.; Mayer, P.; Piotrowski, H.; Vogt, M. Methylated Ammonium and Hydrazinium Salts of 5,5'-Azotetrazolate. Z. Naturforsch. 2001, 56, 847. [CrossRef]

30. Desiraju, G.R.; Steiner, T. The weak Hydrogen Bond in Structural Chemistry and Biology; Oxford University Press: New York, NY, USA, 1999.

31. Matus, M.H.; Arduengo, A.J.; Dixon, D.A. The Heats of Formation of Diazene, Hydrazine, N2H3+, N2H5+, $\mathrm{N} 2 \mathrm{H}$, and N2H3 and the Methyl Derivatives CH3NNH, CH3NNCH3, and CH3HNNHCH3. J. Phys. Chem. A 2006, 110, 10116-10121. [CrossRef]

32. Pittam, D.A.; Pilcher, G. Measurements of heats of combustion by flame calorimetry. Part 8.-Methane, ethane, propane, n-butane and 2-methylpropane. J. Chem. Soc. Faraday Trans. 1972, 68, 2224-2229. [CrossRef]

33. Jiménez, P.; Roux, M.V.; Turrión, C.; Gomis, F. Thermochemical properties of N-heterocyclic compounds I. Enthalpies of combustion, vapour pressures and enthalpies of sublimation, and enthalpies of formation of pyrazole, imidazole, indazole, and benzimidazole. J. Chem. Thermodyn. 1987, 19, 985-992. [CrossRef]

34. Murray, J.S.; Lane, P.; Politzer, P. Relationships between impact sensitivities and molecular surface electrostatic potentials of nitroaromatic and nitroheterocyclic molecules. Mol. Phy. 1995, 85, 1-8. [CrossRef]

35. Murray, J.S.; Lane, P.; Politzer, P. Effects of strongly electron-attracting components on molecular surface electrostatic potentials: Application to predicting impact sensitivities of energetic molecules. Mol. Phys. 1998, 93, 187-194. [CrossRef]

36. Rice, B.M.; Hare, J.J. A quantum mechanical investigation of the relation between impact sensitivity and the charge distribution in energetic molecules. J. Phys. Chem. A 2002, 106, 1770-1783. [CrossRef]

37. Klapötke, T.M. Chemistry of High-Energy Materials, 4th ed.; De Gruyter: Leck, Germany, 2017.

38. Dennington, R.; Keith, T.; Millam, J. GaussView, Version 5; Semichem: Shawnee Mission, KS, USA, 2009.

39. Semenov, N.N. Chemical Kinetics and Chain Reactions; Oxford University Press: New York, NY, USA, 1935.

40. Abramov, V.G.; Vaganova, N.I. Effect of a side reaction with small heat liberation on the critical thermal-explosion condition of the main self-catalyzed reaction. Combust. Explos. Shock Waves 1978, 14, 660-665. [CrossRef]

41. Gołofit, T. Thermal behaviour and safety of 1,3,7,9-tetranitrodibenzo-1,3a,4,6a-tetraazapentalen (z-TACOT). Thermochim. Acta 2018, 667, 59-64. [CrossRef]

42. Hofelich, T.; Thomas, R.C. The use/misuse of the 100 degree rule in the interpretation of thermal hazard tests. In Proceedings of International Symposium on Runaway Reactions; American Institute of Chemical Engineers: Boston, UK; pp. 74-85. 
43. United Nations. Recommendations on the Transport of Dangerous Goods: Manual of Tests and Criteria, 6th ed.; United Nations Publication: New York, NY, USA; Geneva, Switzerland, 2015.

44. Sadchikova, E.V.; Mokrushin, V.S. Synthesis and properties of 5-diazoimidazoles and imidazolyl-5-diazonium salts. Russ. Chem. Bull. 2003, 52, 1600-1605. [CrossRef]

45. Sheldrick, G.M. Crystal structure refinement with SHELXL. Acta Crystallogr. Sect. C 2015, 71, 3-8. [CrossRef] [PubMed]

46. Curtiss, L.A. Assessment of Gaussian-2 and density functional theories for the computation of enthalpies of formation. J. Chem. Phys. 1997, 106, 1063-1079. [CrossRef]

47. Rice, B.M.; Pai, S.V.; Hare, J. Predicting heats of formation of energetic materials using quantum mechanical calculations. Combust. Flame 1999, 118, 445-458. [CrossRef]

48. Byrd, E.F.C.; Rice, B.M. Improved prediction of heats of formation of energetic materials using quantum mechanical calculations. J. Phys. Chem. A 2006, 110, 1005-1013. [CrossRef]

49. Trouton, F. On molecular latent heat. Philos. Mag. 1884, 18, 54-57. [CrossRef]

50. Vyazovkin, S.; Burnham, A.K.; Criado, J.M.; Pérez-Maqueda, L.A.; Popescu, C.; Sbirrazzuoli, N. ICTAC Kinetics Committee recommendations for performing kinetic computations on thermal analysis data. Thermochim. Acta 2011, 520, 1-19. [CrossRef]

51. Srinivas, D.; Ghule, V.D.; Muralidharan, K. Synthesis of nitrogen-rich imidazole, 1,2,4-triazole and tetrazole-based compounds. RSC Adv. 2014, 4, 7041-7051. [CrossRef]

Sample Availability: Samples of the compounds are not available from the authors.

(C) 2020 by the authors. Licensee MDPI, Basel, Switzerland. This article is an open access article distributed under the terms and conditions of the Creative Commons Attribution (CC BY) license (http://creativecommons.org/licenses/by/4.0/). 